\section{D) Check for updates}

Cite this: Org. Biomol. Chem., 2018, 16,6306

\title{
Native chemical ligation at methionine bioisostere norleucine allows for $\mathrm{N}$-terminal chemical protein ligation $\uparrow$
}

\author{
Bo-Tao Xin,\$ Bianca D. M. van Tol, (D) \$ Huib Ovaa* and Paul P. Geurink (D) *
}

The development of $\gamma$-thionorleucine (ThioNle) as a handle for native chemical ligation-desulfurization is reported here. ThioNle is a new addition to the expanding thiolated amino acid toolbox and serves as a methionine substitute in NCL with the advantage that it lacks the undesirable oxidation-prone thioether moiety. Its usefulness for $\mathrm{N}$-terminal ubiquitination is demonstrated by efficient preparation of fully synthetic linear diubiquitin with preserved protein folding compared to the expressed material. Interestingly, gel-based deubiquitinating assays revealed that the methionine to norleucine substitution did affect diubiquitin cleavage, which may indicate a more profound role for methionine in the interaction between ubiquitin and the deubiquitinating enzymes than has been known so far.

Received 10th July 2018,

Accepted 9th August 2018

DOI: $10.1039 / c 80 b 01627 e$

rsc.li/obc with an N-terminal methionine residue, NCL at these sites would allow for the N-terminal modification of proteins. ${ }^{16} \mathrm{~A}$ well-known $\mathrm{N}$-terminal modification is linear ubiquitination which is an important post-translational modification. ${ }^{17}$ NCL at internal methionine sites has been performed by applying homocysteine as a thiol donor followed by $S$-methylation

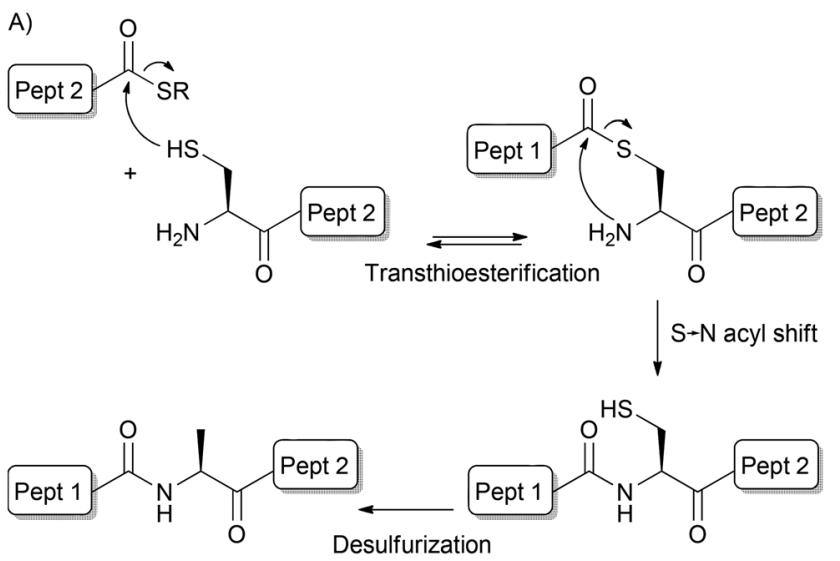

B)

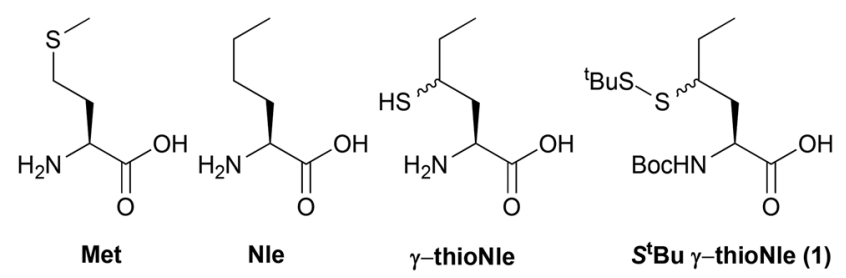

Fig. 1 (A) Native chemical ligation-desulfurization. (B) Structures of methionine, norleucine, $\gamma$-thionorleucine and target compound 1. 
under carefully controlled conditions to prevent over- and undermethylation of homocysteine or mismethylation of other residues. ${ }^{18}$ Desulfurization of the homocysteine ligation product has also been reported which effectively leads to the mutation of methionine into 2-aminobutyric acid in the final peptide. ${ }^{2}$ Thiomethionine is currently missing from the thiolated amino acid collection; yet it would serve as an attractive handle for the N-terminal modification of proteins by means of NCL. On the other hand, the thioether moiety in methionine is susceptible to oxidation into a sulfoxide or even a sulfone, and this occurs rapidly under aerobic conditions, which often results in a significant loss of bioactivity of the synthesized protein. ${ }^{19}$ In addition, the different oxidation states of methionine often lead to a mixture of different molecular weights for a single protein, which complicates the analysis by mass spectrometry. This is especially detrimental to the desulfurization reaction, typically monitored by mass spectrometry, since double oxidation or single oxidation of two methionine residues results in a net mass increase of $32 \mathrm{Da}$, which is exactly the mass decrease upon effective removal of sulfur during desulfurization. Hence, an overall change in mass is not observed although desulfurization is completed. In order to overcome these limitations, methionine is typically substituted by its closer isostere norleucine (Nle) (Fig. 1B), without substantially affecting the peptide or protein structure and function as described in the literature. ${ }^{19}$ We here present the synthesis of $\gamma$-thionorleucine (Fig. 1B) and its application in NCL for N-terminal ubiquitination.

\section{Results and discussion}

As $\gamma$-thionorleucine is installed onto peptides by means of solid-phase peptide synthesis (SPPS) we prepared appropriately protected $N$-Boc, $S$-tert-butylsulfide $\gamma$-thionorleucine $\mathbf{1}$ (Fig. 1B), as depicted in Scheme 1. The synthesis commenced with the preparation of tert-butyl (S)-2,2-dimethyl-4-(2oxoethyl)oxazolidine-3-carboxylate 2 according to literature procedures. ${ }^{20}$ Addition of ethylmagnesium bromide to aldehyde $\mathbf{2}$ yielded compound $\mathbf{3}$ as a mixture of two diastereomers and the synthesis was continued with this mixture. The free hydroxyl was protected as benzyl ether (4), which was subsequently treated with Jones reagent to hydrolyse the acetonide and concomitantly oxidize the resulting alcohol to a carboxylic acid. This was converted into the corresponding tert-butyl ester 5 upon treatment with $O$-tert-butyl $N, N^{\prime}$-diisopropylisourea. ${ }^{21}$ Palladium-catalysed hydrogenation and subsequent mesylation of the alcohol intermediate resulted in methanesulfonate 6, which was transformed to acetylated thiol 7 upon treatment with potassium thioacetate. tert-Butyl disulfide $\mathbf{8}$ was obtained after treating compound 7 with $S$-tert-butyl methane thiosulfonate, hydroxylamine and $\mathrm{Et}_{3} \mathrm{~N}^{22}$ TFA treatment and subsequent instalment of a Boc protecting group resulted in target compound 1 .

The ability of the thioNle building block to function as a new native chemical ligation handle was assessed by

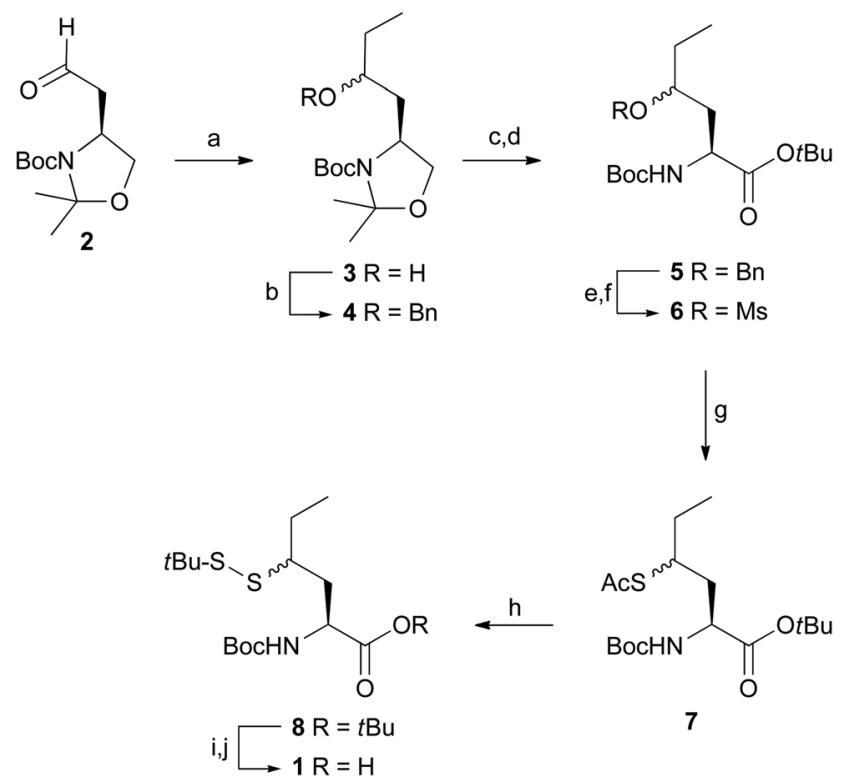

Scheme 1 Synthesis of $\gamma$-thionorleucine. Reagents and conditions: (a) $\mathrm{EtMgBr}, \mathrm{Et}_{2} \mathrm{O}, 93 \%$; (b) $\mathrm{BnBr}, \mathrm{NaH}, n-\mathrm{Bu}_{4} \mathrm{NI}, \mathrm{DMF}, 0{ }^{\circ} \mathrm{C}, 44 \%$; (c) Jones reagent, acetone; (d) $\mathrm{O}$-tert-butyl $\mathrm{N}, \mathrm{N}^{\prime}$-diisopropylisourea, THF, $60{ }^{\circ} \mathrm{C}$, $70 \%$; (e) $\mathrm{Pd} / \mathrm{C}$ (10\% wt), $\mathrm{H}_{2}$ (4 bar), $\mathrm{MeOH}, 48$ h; (f) MsCl, Et ${ }_{3} \mathrm{~N}, \mathrm{DCM}, 63 \%$; (g) $\mathrm{KSAc}, 65{ }^{\circ} \mathrm{C}, 18 \mathrm{~h}, 60 \%$; (h) S-tert-butyl methane thiosulfonate, $\mathrm{HONH}_{2} \cdot \mathrm{HCl}, \mathrm{Et}_{3} \mathrm{~N}, \mathrm{MeOH}, 63 \%$; (i) TFA; (j) $\mathrm{Boc}_{2} \mathrm{O}, \mathrm{K}_{2} \mathrm{CO}_{3}, \mathrm{THF}, \mathrm{H}_{2} \mathrm{O}, 50 \%$.

$\mathrm{N}$-terminal protein ubiquitination. We chose to ubiquitinate ubiquitin (Ub), which effectively results in a linear diubiquitin (diUb) species. Ubiquitination is a post-translational protein modification that plays an important role in virtually all biological processes. ${ }^{23}$ Poly-ubiquitination involves the instalment of multiple successively linked Ubs to a protein and the amino acid residue involved in the linkage between two Ubs (any of its seven lysine residues or the N-terminal Met) determines the eventual biological signal. For example, the canonical polyUb linkage Lys-48 targets the tagged protein for proteasomal degradation. Linear Ub chains (e.g. coupled via Met-1) on the other hand play a key role in the regulation of NF-kB signalling and cell death. ${ }^{24}$ We and others have developed chemical synthesis methods for the generation of all seven isopeptidelinked (e.g. via a Lys side chain) Ub linkages using NCL which have led to many new biological insights. ${ }^{14 a, 25}$ However, a method to synthesize the linear Ub linkage has been lacking so far.

Linear diUb was constructed by NCL between a Ub-thioester and $\gamma$-thioNle-containing Ub (Scheme 2). The individual Ub proteins were synthesized by Fmoc-based linear SPPS. ${ }^{14 a}$ Compound 1 was coupled to $\operatorname{Ub}(2-76) 9$ on resin under standard coupling conditions, followed by global deprotection under strong acidic conditions and RP-HPLC purification, which resulted in $\mathrm{Ub}\left(1-76\right.$, ThioNle $\left.{ }_{1}\right) \mathbf{1 1}$ in multi-milligram amounts. LC-MS analysis of compound 11 resulted in two similar peaks at different retention times but of identical mass (Fig. 2A). We believe that these represent the two diastereomers of compound 11, having the racemic $\gamma$-carbon atom in 

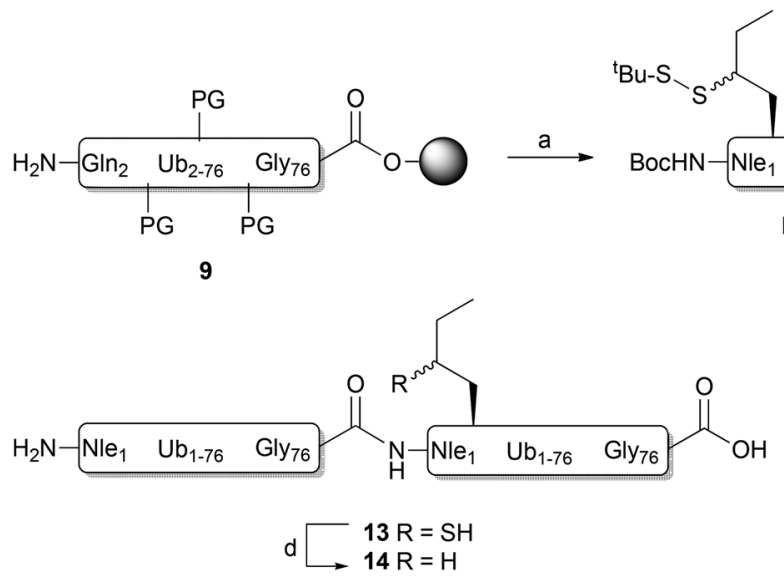

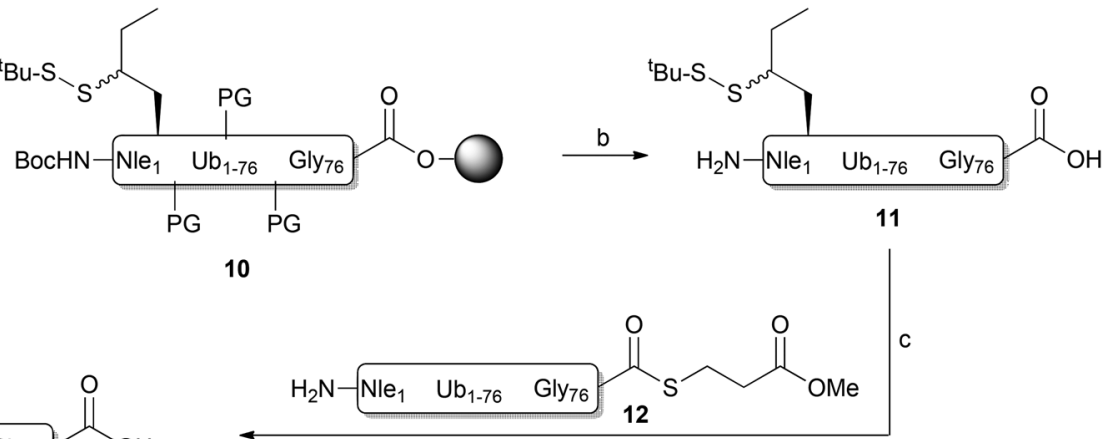

Scheme 2 Synthesis of linear diUb. Reagents and conditions: (a) compound 1, PyBOP, DiPEA, NMP; (b) TFA, H2O, TIS, phenol, 38\%; (c) TCEP, MPAA, $6 \mathrm{M}$ Gnd $\cdot \mathrm{HCl}, 0.15 \mathrm{M}$ sodium phosphate, $\mathrm{pH} 7.5,37^{\circ} \mathrm{C}, 27 \%$; (d) VA-044, TCEP, GSH, $6 \mathrm{M}$ Gnd. $\mathrm{HCl}, 0.15 \mathrm{M}$ sodium phosphate, $\mathrm{pH} 7.0,37^{\circ} \mathrm{C}, 93 \%$.

thioNle as indicated in Scheme 2. Ub(1-75) was prepared by SPPS on a hyper-acid-labile trityl resin and protected with a Boc group at the N-terminus. Subsequently, the protein was cleaved from the resin under mild acidic conditions (20 vol\% HFIP in DCM) which liberated only the C-terminal carboxylic acid without affecting the other protecting groups. The C-terminus was activated after which methyl-3-(glycylthio)propionate was coupled, followed by global deprotection and RP-HPLC purification to result in $\mathrm{Ub}(1-76)$-thioester 12. A first attempt for the NCL between Ub-thioester 12 and $\gamma$-thioNle-Ub 11 under previously reported conditions (e.g. $50 \mathrm{mg} \mathrm{mL}^{-1}$ in $6 \mathrm{M}$ Gnd $\cdot \mathrm{HCl} / 0.15 \mathrm{M}$ sodium phosphate buffer, $\mathrm{pH}$ 7.6, $250 \mathrm{mM} \mathrm{MPAA})^{26}$ resulted in only trace amounts of the desired dimer 13, which according to LC-MS analysis was caused by the slow reduction of the tert-butyldisulfide moiety in $\gamma$-thioNle. Apparently, compared to the reported correspondingly thio-protected $\gamma$-thioLys, which is readily reduced by MPAA, the tert-butyldisulfide moiety in $\gamma$-thioNle is much more stable. A preincubation of $\mathbf{1 1}$ with $100 \mathrm{mM}$ TCEP for $90 \mathrm{~min}$ at $37^{\circ} \mathrm{C}$ readily resulted in the fully liberated thiol moiety as evidenced from LC-MS analysis shown in Fig. 2B. Efficient NCL was achieved using a $40 \mathrm{mg} \mathrm{mL}^{-1}$ final Ub concentration and $250 \mathrm{mM}$ MPAA for 2 hours at $37{ }^{\circ} \mathrm{C}$ according to LC-MS analysis (Fig. 2C and D), which indicated nearly full consumption of the thioNle-containing $\mathrm{Ub}$ and hydrolysis of remaining Ub-thioester excess. Intermediate 13 was obtained after RP-HPLC purification. The desulfurization under standard radical conditions proceeded smoothly and a subsequent purification by RP-HPLC and gel filtration yielded the target linear diUb 14 in a good overall yield (2.5 mg, 25\% after NCL-deS) and purity, as confirmed by LC-MS (Fig. 2E and ESI $\dagger$ ) and SDS-PAGE analysis (Fig. S1 in the ESI $\dagger$ ).

Correct folding of the purified synthetic linear diUb was verified by circular dichroism (CD) spectroscopy (Fig. 3A). The spectra of synthetic and purified expressed recombinant linear diUb were recorded and compared. Similar curves were obtained for both constructs, which indicates correct protein folding of synthetic linear diUb. To verify the biochemical function we compared synthetic and expressed linear diUb by enzymatic cleavage experiments. Deubiquitinase (DUB)mediated cleavage of synthetic and expressed linear diUb was assessed using OTULIN, USP16, and USP21, three well-studied DUBs from the two largest DUB families, which are known to cleave the linear Ub linkage. ${ }^{25}$ Synthetic and expressed diUb were incubated with the three DUBs at $37^{\circ} \mathrm{C}$ and the reaction samples were taken and immediately denatured at different time points. All proteins were resolved by SDS-PAGE and visualized by InstantBlue staining. The cleavage of diUb into monoUb is revealed by the disappearance of the diUb protein band and appearance of the monoUb protein band (Fig. 3B). Indeed, synthetic linear diUb is recognized and appropriately processed by all three DUBs, demonstrating proper protein folding and biochemical function.

Interestingly, there appears to be a difference in the cleaving efficiency by the DUBs of synthetic diUb compared to expressed linear diUb, although for USP21 this difference is very small. As proper folding of the synthetic construct was confirmed by CD measurements (Fig. 3A) the observed difference in hydrolysis rates could likely be attributed to the methionine to norleucine substitution. OTULIN is specific for linear Ub chains, and the positioning of the Ub-Ub linkage in the active site was assigned with atomic resolution. ${ }^{27}$ From the crystal structures (PDB: 3ZNZ and 5OE7) it becomes apparent that the Ub methionine side chain points outwards from the active site and is probably not directly involved in the binding between enzyme and substrate. Our observation that the methionine to norleucine substitution affects the hydrolysis rate may therefore indicate that the thioether moiety in methionine is important for the interaction between $\mathrm{Ub}$ and OTULIN. Except for the finding that Met-1 sulfur can form a hydrogen bond with the Lys-63 backbone amine and that oxidation of this sulfur or Met-1 deletion affects the Ub folding below $\mathrm{pH}$ $4,{ }^{28}$ little is known about the contribution of methionine to the biochemical function of Ub. As no structural data on the linear Ub-Ub linkage within the USP16 and USP21 active sites 
A) Compound 11
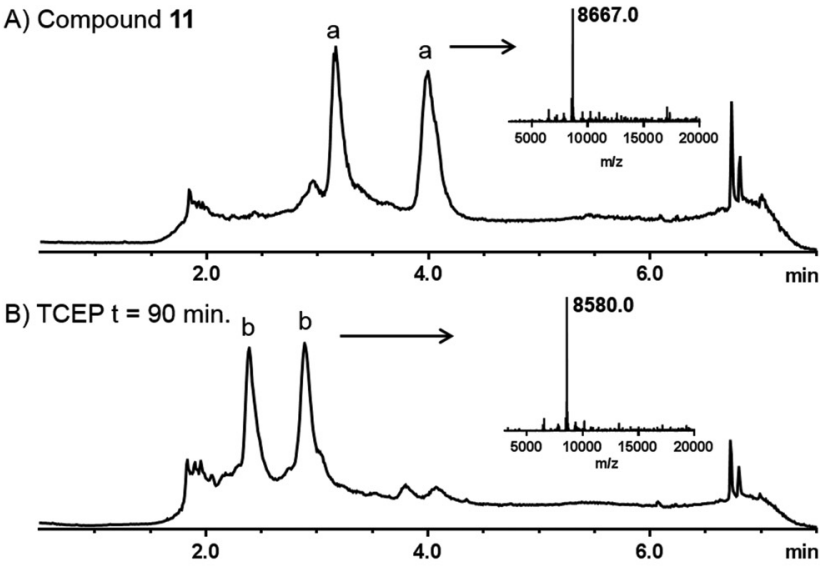

C) Ligation $\mathrm{t}=0 \mathrm{~min}$.

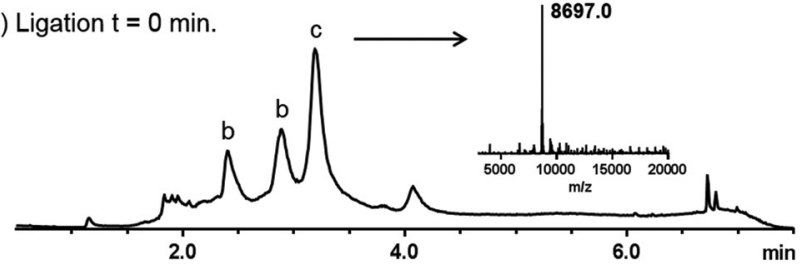

D) Ligation $\mathrm{t}=120 \mathrm{~min}$.

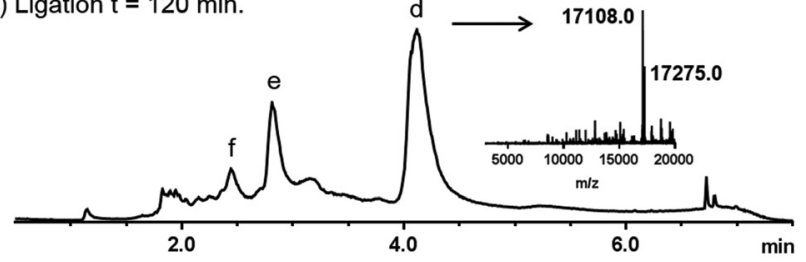

E) Desulfurization and HPLC

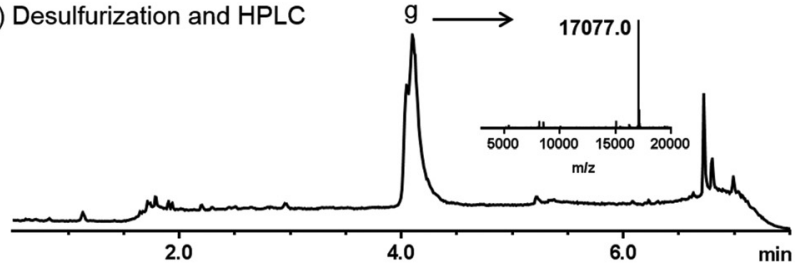

Fig. 2 Analytical LC-MS analysis of the NCL-deS reactions. Mass traces of (A) purified compound 11, (B) preincubation of 11 with TCEP, (C) ligation reaction between 11 and 12 at $t=0 \mathrm{~min}$, (D) ligation reaction between 11 and 12 at $t=120 \mathrm{~min}$, and $(\mathrm{E})$ product after desulfurization and purification. The insets in each trace represent the deconvoluted mass spectra of the indicated peaks. $a=$ compound $11, b=$ reduced disulfide of 11 (free thiol), $c=$ MPAA ester of $12, d$ = ligation product (mixture of free thiol and MPAA disulfide), $e=$ hydrolysed Ub-thioester (8547 Da), $f=$ assumed Ub-Gnd. Adduct (8588 Da), $g=$ compound 14 (the small shoulder has a mass identical to the main peak and might indicate a different conformation; see also the ESI $\dagger$ ).

are available, the importance of the methionine residue for these DUBs remains to be investigated.

The development of $\gamma$-thionorleucine proved valuable as the NCL-des construction of linear diUb proceeded efficiently and concomitantly omitted all mass spectrometry disadvantages associated with methionine oxidation. Unexpectedly, the methionine to norleucine substitution did affect the DUB mediated diUb cleavage, which may indicate a more profound role for methionine in the interaction between Ub and DUB than has been known so far.
A)
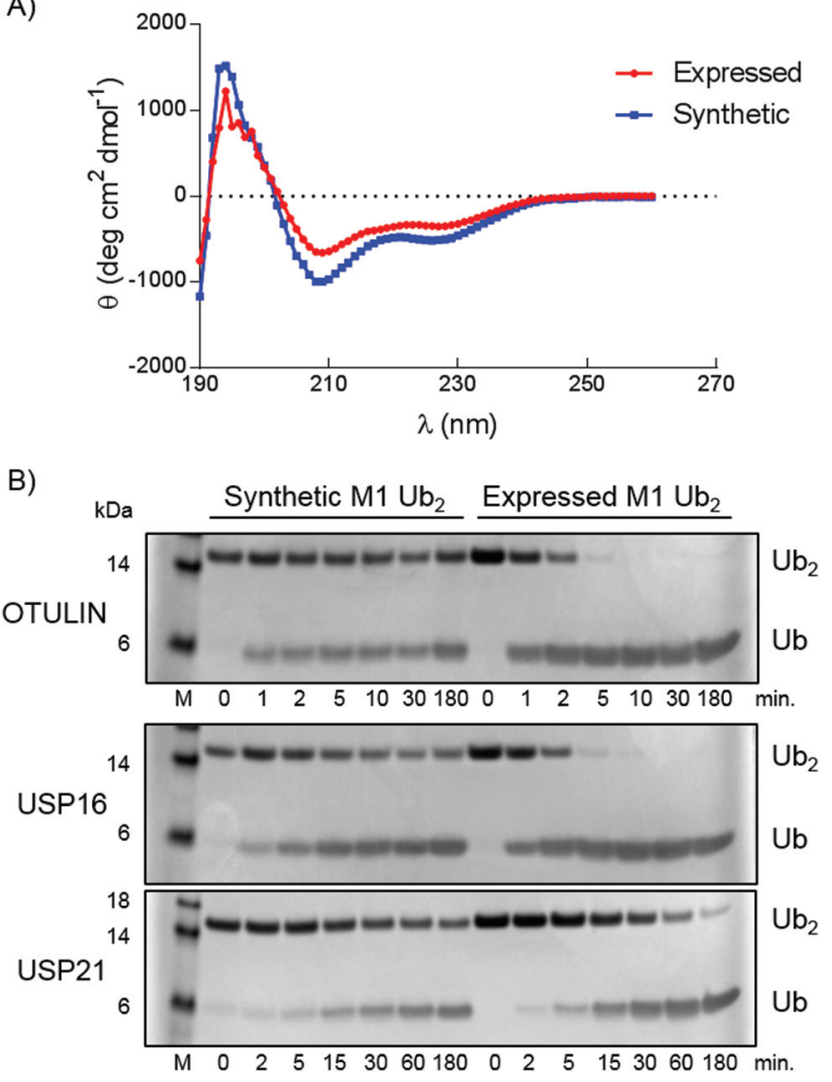

Fig. 3 Characterization of synthetic linear diUb (14). (A) CD measurements of synthetic and expressed linear diUb. (B) SDS-PAGE analysis of linear diUb cleavage by OTULIN, USP16 and USP21.

\section{Conclusions}

In summary, we presented thioNle as a new handle for NCL and showed its feasibility for the N-terminal modification of proteins by preparing linear diubiquitin in a fully synthetic way for the first time. ThioNle is a new addition to the expanding thiolated amino acid toolbox and serves as a suitable methionine substitute in NCL with the advantage that it lacks the undesirable oxidation-prone thioether moiety. In addition, the fully synthetic preparation of linear diUb opens the way for the creation of linear diUb-based constructs, such as activitybased probes and assay reagents, which will benefit the field of Ub research. ${ }^{27 b}$

\section{Experimental section}

\section{General}

General reagents were obtained from Sigma Aldrich, Biosolve, Fluka and Acros, and used as received. Solvents were purchased from Biosolve or Sigma Aldrich. Dry THF and DCM were obtained using an Innovative Technology PureSolv Micro Solvent Purification System. Peptide synthesis reagents were purchased from NovaBiochem and Rapp Polymers. Analytical thin layer chromatography (TLC) was performed on Merck alu- 
minium sheets (pre-coated with silica gel $60 \mathrm{~F}_{254}$ ). Compounds were visualized by UV adsorption $(254 \mathrm{~nm}$ ) and/or by using a solution of $\mathrm{KMnO}_{4}\left(7.5 \mathrm{~g} \mathrm{~L}^{-1}\right)$ and $\mathrm{K}_{2} \mathrm{CO}_{3}\left(50 \mathrm{~g} \mathrm{~L}^{-1}\right)$ in water and charring. Column chromatography was carried out on silica gel (40-63 u, $60 \AA$ A, Fluorochem). NMR spectra $\left({ }^{1} \mathrm{H},{ }^{13} \mathrm{C}\right)$ were recorded on a Bruker Ultrashield 300 Spectrometer $\left({ }^{1} \mathrm{H}: 300.17 \mathrm{MHz},{ }^{13} \mathrm{C}\right.$ : $\left.75.47 \mathrm{MHz}\right)$ at $298 \mathrm{~K}$. Peak shapes in NMR spectra are indicated with symbols 'd' (doublet), 's' (singlet), 't' (triplet) and 'm' (multiplet). Chemical shifts $(\delta)$ are given in ppm relative to $\mathrm{CDCl}_{3}$ as an internal standard.

\section{LC-MS}

LC-MS measurements were performed on an LC-MS system equipped with a Waters 2795 Separation Module (Alliance HT), a Waters 2996 Photodiode Array Detector (190-750 nm), a Waters Xbridge C18 column $(2.1 \times 30 \mathrm{~mm}, 3.5 \mu \mathrm{m})$ or a Waters Xbridge C18 column $(2.1 \times 100 \mathrm{~mm}, 3.5 \mu \mathrm{m})$ and a LCT ESI-Orthogonal Acceleration Time of Flight Mass Spectrometer. Samples were run using 2 mobile phases: $\mathrm{A}=$ $1 \% \mathrm{CH}_{3} \mathrm{CN}$ and $0.1 \%$ formic acid in water and $\mathrm{B}=1 \%$ water and $0.1 \%$ formic acid in $\mathrm{CH}_{3} \mathrm{CN}$. Data processing was performed using Waters MassLynx Mass Spectrometry Software 4.1 (deconvolution with Maxent1 function).

Program 1: Waters Xbridge C18 column $(2.1 \times 30 \mathrm{~mm}$, $3.5 \mu \mathrm{m}$ ); flow rate $=0.8 \mathrm{~mL} \mathrm{~min}^{-1}$, runtime $=6.2 \mathrm{~min}$, column $T=40{ }^{\circ} \mathrm{C}$, mass detection: 300-2000 Da. Gradient: 0-0.2 min: $5 \% \mathrm{~B} ; 0.2-3.2 \mathrm{~min}: 5 \% \rightarrow 95 \% \mathrm{~B} ; 3.2-4.2 \mathrm{~min}: 95 \% \mathrm{~B}$; 4.2-4.4 min: $95 \% \rightarrow 5 \% \mathrm{~B}$; 4.4-6.2 $\min : 5 \% \mathrm{~B}$.

Program 2: Waters Xbridge C18 column $(2.1 \times 100 \mathrm{~mm}$, $3.5 \mu \mathrm{m}$ ); flow rate $=0.4 \mathrm{~mL} \mathrm{~min}^{-1}$, runtime $=13 \mathrm{~min}$, column $T=40{ }^{\circ} \mathrm{C}$, mass detection: 300-2000 Da. Gradient: 0-0.4 min: 5\% B; 0.4-9.0 min: $5 \% \rightarrow$ 95\% B; 9.0-11.2 $\min : 95 \% \mathrm{~B}$; 11.2-11.3 min: $95 \% \rightarrow 5 \% \mathrm{~B}$; $11.3-13.00 \mathrm{~min}: 5 \% \mathrm{~B}$.

LC-MS analysis of diUb as well as the TCEP reduction, NCL and desulfurization reactions (as shown in Fig. 2) were recorded on a Waters XEVO-G2 XS Q-TOF mass spectrometer equipped with an electrospray ion source in positive mode (capillary voltage: $1.2 \mathrm{kV}$, desolvation gas flow: $900 \mathrm{~L} \mathrm{~h}^{-1}$, temperature: $60{ }^{\circ} \mathrm{C}$ ) with a resolution $R=26000$. Samples were run using 2 mobile phases: $\mathrm{A}=0.1 \%$ formic acid in water and $\mathrm{B}=0.1 \%$ formic acid in $\mathrm{CH}_{3} \mathrm{CN}$ on a Waters Acquity UPLC Protein BEH C4 column, $300 \AA$ A, $1.7 \mu \mathrm{m}(2.1 \times 50 \mathrm{~mm})$; flow rate $=0.6 \mathrm{~mL} \mathrm{~min}{ }^{-1}$, runtime $=10.00 \mathrm{~min}$, column $T=60{ }^{\circ} \mathrm{C}$, mass detection: 50-1500 Da. Gradient: 0-0.80 min: 2\% B; 0.80-1.00 $\min : 2 \% \rightarrow 23 \% \mathrm{~B} ; 1.00-1.50: 23 \% \mathrm{~B} ; 1.50-3.00 \mathrm{~min}:$ $23 \% \rightarrow 25.5 \%$ B; $3.00-3.30$ min: $25.5 \%$ B; $3.30-3.50$ min: $25.5 \% \rightarrow 29 \%$ B; 3.50-4.50: $29 \% \rightarrow 32 \%$ B; $4.50-6.50$ min: $32 \% \rightarrow 100 \%$ B; $6.50-8.00$ min: $100 \%$ B; $8.00-8.10$ min: $100 \% \rightarrow 2 \%$ B; 8.10-10.00 min: 2\% B. Data processing was performed using Waters MassLynx Mass Spectrometry Software 4.1.

\section{HRMS measurements}

High resolution mass spectra were recorded on a Waters XEVO-G2 XS Q-TOF mass spectrometer equipped with an elec- trospray ion source in positive mode (capillary voltage: $3.0 \mathrm{kV}$, desolvation gas flow: $900 \mathrm{~L} \mathrm{~h}^{-1}$, temperature: $60{ }^{\circ} \mathrm{C}$ ) with a resolution $R=22000$ and $200 \mathrm{pg} \mu \mathrm{L}^{-1}$ Leu-Enk $(\mathrm{m} / \mathrm{z}=$ 556.2771) as a "lock mass". Samples were run using 2 mobile phases: $\mathrm{A}=0.1 \%$ formic acid in water and $\mathrm{B}=0.1 \%$ formic acid in $\mathrm{CH}_{3} \mathrm{CN}$ on a Waters Acquity UPLC BEH C18 column

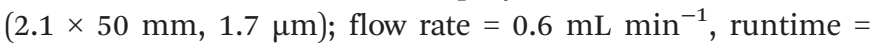
$3.00 \mathrm{~min}$, column $T=60{ }^{\circ} \mathrm{C}$, mass detection: 50-1500 Da. Gradient: $0-0.15 \min : 2 \% \mathrm{~B}$; 0.15-1.85 min: $2 \% \rightarrow 100 \% \mathrm{~B}$; 1.85-2.05: $100 \% \quad \mathrm{~B} ; \quad 2.05-2.10 \mathrm{~min}: 100 \% \rightarrow 2 \% \quad \mathrm{~B}$; 2.10-3.00 min: $100 \%$ B. Data processing was performed using Waters MassLynx Mass Spectrometry Software 4.1.

\section{HPLC purification}

HPLC purifications were performed on a Waters HPLC equipped with a Waters 2489 UV/Vis detector, Waters fraction collector III and Waters XBridge prep C18 OBD $(30 \times 150 \mathrm{~mm}$, $5 \mu \mathrm{m})$. Flowrate $=37.5 \mathrm{~mL} \min ^{-1}$. Mobile phase: $\mathrm{A}=\mathrm{H}_{2} \mathrm{O}, \mathrm{B}=$ $\mathrm{CH}_{3} \mathrm{CN}$ and $\mathrm{C}=1 \%$ TFA in $\mathrm{H}_{2} \mathrm{O}$. Gradient: $0-5 \mathrm{~min}: 90 \% \mathrm{~A}$, $5 \%$ B, 5\% C; 5-7 min: $5 \rightarrow 20 \%$ B, 5\% C; 7-18 min: $20 \rightarrow 45 \%$ B, 5\% C; $18-18.5$ min: $45 \% \rightarrow 95 \%$ B, 5\% C; $18.5-21.6$ min: 95\% B, 5\% C; 21.6-25 min: 95\% $\rightarrow$ 5\% B, 5\% C.

Alternatively, a Shimadzu LC-20AT equipped with a Shimadzu SPD-20A UV/Vis detector and a Shimadzu FRC-10A fraction collector and a Waters XBridge C18-Prep column $(10 \times$ $150 \mathrm{~mm}, 5 \mu \mathrm{m})$ was used. Flowrate $=4.00$ or $6.50 \mathrm{~mL} \mathrm{~min}{ }^{-1}$. Mobile phase: $\mathrm{A}=0.05 \%$ TFA in $\mathrm{H}_{2} \mathrm{O}$ and $\mathrm{B}=0.05 \%$ TFA in $\mathrm{CH}_{3}$ CN. $T=40{ }^{\circ} \mathrm{C}$. Gradient: $0-8.20 \mathrm{~min}: 5 \%$ B $(4.00 \mathrm{~mL}$ $\min ^{-1}$ ) and $0-1 \mathrm{~min}: 5 \% \mathrm{~B} ; 1 \rightarrow 2 \min 5 \% \rightarrow 10 \% \mathrm{~B} ; 2-17 \mathrm{~min}:$ $10 \% \rightarrow 70 \% \mathrm{~B} ;$ 17-17.10 min: $70 \% \rightarrow$ 95\% B; 17.10-19.10 min: 95\% B; 19.10-22.10: 5\% B.

\section{Synthesis of $\boldsymbol{\gamma}$-thionorleucine}

tert-Butyl (4S)-4-(2-hydroxybutyl)-2,2-dimethyloxazolidine-3carboxylate (3). Compound 2 (6.1 g, $25.1 \mathrm{mmol})$, which was synthesized according to literature procedures, ${ }^{20}$ was dissolved in dry $\mathrm{Et}_{2} \mathrm{O}(60 \mathrm{~mL})$ and the reaction mixture was stirred at room temperature under an argon atmosphere, followed by the dropwise addition of ethylmagnesium bromide (2 eq., $5.99 \mathrm{~g}$, $50.2 \mathrm{mmol}, 16.7 \mathrm{~mL}$ of a $3 \mathrm{M}$ solution in diethyl ether). The stirring was continued for $1 \mathrm{~h}$ and TLC analysis showed the complete conversion of the starting material. The reaction was quenched by adding water $(5 \mathrm{~mL})$ and the resulting mixture was filtered through a Celite pad. The filtrate was washed with $\mathrm{H}_{2} \mathrm{O}$ and brine, dried over $\mathrm{MgSO}_{4}$ and concentrated in vacuo. Purification by silica gel flash column chromatography (EtOAc/ heptane $5 \% \rightarrow 30 \%$ ) yielded the title compound $(6.4 \mathrm{~g}$, $23.4 \mathrm{mmol}, 93 \%)$. NMR data were collected based on two pure diastereoisomers and compared with reported data. ${ }^{29}$ The first eluting compound: ${ }^{1} \mathrm{H}$ NMR (300 MHz, $\mathrm{CDCl}_{3}$ ) $\delta 4.22-4.16(\mathrm{~m}$, $1 \mathrm{H}, \alpha \mathrm{CH}$ ), 3.95 (dd, $J=8.7,5.4 \mathrm{~Hz}, 1 \mathrm{H}, \mathrm{OCH}_{2}$ in ring), 3.62 (d, $J=8.6 \mathrm{~Hz}, 1 \mathrm{H}, \mathrm{OCH}_{2}$ in ring), 3.42-3.29 (m, $\left.1 \mathrm{H}, \mathrm{OCH}\right), 1.74$ (ddd, $\left.J=13.6,11.1,2.3 \mathrm{~Hz}, 1 \mathrm{H}, \frac{1}{2} \times \beta \mathrm{CH}_{2}\right), 1.51-1.42(\mathrm{~m}, 18 \mathrm{H}$, $\left.2 \times \mathrm{CH}_{2}, 3 \times \mathrm{CH}_{3}, \frac{1}{2} \times \beta \mathrm{CH}_{2}, \delta \mathrm{CH}_{2}\right), 0.89\left(\mathrm{t}, J=7.4 \mathrm{~Hz}, 3 \mathrm{H}, \mathrm{CH}_{3}\right)$. The second eluting compound: ${ }^{1} \mathrm{H}$ NMR (300 $\mathrm{MHz}, \mathrm{CDCl}_{3}$ ) $\delta$ 4.16-4.04 (m, 1H, $\alpha \mathrm{CH}$ ), 3.95 (dd, $J=9.0,5.7 \mathrm{~Hz}, 1 \mathrm{H}, \mathrm{OCH}_{2}$ ), 
3.90-3.73 (m, 1H, $\left.\mathrm{OCH}_{2}\right), 3.55-3.49(\mathrm{~m}, 1 \mathrm{H}, \mathrm{OCH}), 2.60(\mathrm{~s}, 1 \mathrm{H}$, $\mathrm{OH}), 1.76\left(\mathrm{t}, J=6.1 \mathrm{~Hz}, 1 \mathrm{H}, \frac{1}{2} \times \beta \mathrm{CH}_{2}\right), 1.60-1.46(\mathrm{~m}, 18 \mathrm{H}, 2 \times$ $\left.\mathrm{CH}_{2}, 3 \times \mathrm{CH}_{3}, \frac{1}{2} \times \beta \mathrm{CH}_{2}, \delta \mathrm{CH}_{2}\right), 0.93\left(\mathrm{t}, J=7.4 \mathrm{~Hz}, 3 \mathrm{H}, \mathrm{CH}_{3}\right)$.

tert-Butyl (4S)-4-(2-(benzyloxy)butyl)-2,2-dimethyloxazolidine-3-carboxylate (4). Compound 3 (6.4 g, $23.4 \mathrm{mmol}$ ) was dissolved in DMF (100 $\mathrm{mL})$ and the reaction solution was cooled to $0{ }^{\circ} \mathrm{C}$, followed by the addition of $n-\mathrm{Bu}_{4} \mathrm{NI}$ (0.1 eq., $0.85 \mathrm{~g}, 2.3 \mathrm{mmol}$ ) and sodium hydride (1.2 eq., $1.1 \mathrm{~g}$, $28.1 \mathrm{mmol}, 60 \%$ dispersion in mineral oil). After stirring at $0{ }^{\circ} \mathrm{C}$ for another $30 \mathrm{~min}$, benzyl bromide $(2.0$ eq., $8.00 \mathrm{~g}$, $46.8 \mathrm{mmol}, 5.6 \mathrm{~mL}$ ) was added dropwise. The resulting mixture was stirred for $1.5 \mathrm{~h}$ at room temperature. Then saturated aqueous $\mathrm{NH}_{4} \mathrm{Cl}$ was added and the mixture was extracted with $\mathrm{Et}_{2} \mathrm{O}(3 \times)$. The combined organic layer was washed with water and brine, dried over $\mathrm{MgSO}_{4}$ and concentrated in vacuo. Purification by silica gel flash column chromatography (EtOAc/ heptane $2 \% \rightarrow 15 \%$ ) yielded the title compound as a mixture of diastereoisomers $(3.7 \mathrm{~g}, 10.2 \mathrm{mmol}, 44 \%) .{ }^{1} \mathrm{H} \quad \mathrm{NMR}$ $\left(300 \mathrm{MHz}, \mathrm{CDCl}_{3}\right) \delta=7.40-7.22(\mathrm{~m}, 5 \mathrm{H}, \mathrm{Ph}), 4.60-4.35(\mathrm{~m}, 2 \mathrm{H}$, $\left.\mathrm{OCH}_{2}\right), 4.22-4.01(\mathrm{~m}, 1 \mathrm{H}, \alpha \mathrm{CH}), 3.98-3.74\left(\mathrm{~m}, 2 \mathrm{H}, \mathrm{CH}_{2}\right.$ in ring), 3.56-3.27 (m, 1H, OCH), 2.03-1.76 (m, $\left.1 \mathrm{H}, \beta_{\mathrm{CH}_{2}}\right)$, 1.72-1.51 (m, 5H, $\left.\delta \mathrm{CH}_{2}, \mathrm{CH}_{3}\right), 1.50-1.42\left(\mathrm{~m}, 13 \mathrm{H}, \beta_{\mathrm{CH}}, 4 \times\right.$ $\left.\mathrm{CH}_{3}\right), 0.94\left(\mathrm{t}, J=7.4 \mathrm{~Hz}, 3 \mathrm{H}, \mathrm{CH}_{3}\right) \mathrm{ppm} .{ }^{13} \mathrm{C} \mathrm{NMR}(75 \mathrm{MHz}$, $\left.\mathrm{CDCl}_{3}\right) \delta=138.90,128.43,128.37,127.77,127.53,79.09,77.50$, $70.67,68.38,66.98,56.89,54.67,38.16,37.50,36.81,28.62$, 28.40, 27.06, 26.83, 26.33, 24.70, 23.38, 14.19 ppm. HRMS: calculated for $\mathrm{C}_{21} \mathrm{H}_{33} \mathrm{NO}_{4}[\mathrm{M}+\mathrm{H}]^{+} 364.2488$; found 364.2473.

(2S)-4-(Benzyloxy)-2-((tert-butoxycarbonyl)amino)hexanoic acid. Jones reagent (2.5 eq., $25.5 \mathrm{mmol}, 12.8 \mathrm{~mL}, 2 \mathrm{M}$ in aqueous sulfuric acid) was added to a solution of compound 4 (3.7 g, $10.2 \mathrm{mmol})$ in acetone $(140 \mathrm{~mL})$ at $0^{\circ} \mathrm{C}$. Stirring was continued for $5 \mathrm{~h}$ and the reaction was quenched by adding isopropanol $(88 \mathrm{~mL})$. The resulting reaction mixture was stirred for $10 \mathrm{~min}$ and the $\mathrm{pH}$ was adjusted to 4-5 with saturated aqueous $\mathrm{NaHCO}_{3}$. The mixture was extracted with EtOAc $(3 \times)$ and the combined organic layer was washed with $\mathrm{H}_{2} \mathrm{O}$ and brine, dried over $\mathrm{MgSO}_{4}$ and concentrated in vacuo. The crude product was directly used in the next step without further purification.

tert-Butyl (2S)-4-(benzyloxy)-2-((tert-butoxycarbonyl)amino) hexanoate (5). The crude product obtained from the previous step was co-evaporated with toluene $(3 \times)$ and dissolved in dry THF ( $25 \mathrm{~mL}$ ), followed by the addition of a solution of $\mathrm{O}$-tertbutyl $N, N^{\prime}$-diisopropylisourea ${ }^{21}$ (1.5 eq., $3.1 \mathrm{~g}, 15.3 \mathrm{mmol}$ ) in THF (15 mL). The reaction mixture was stirred for $3 \mathrm{~h}$ at $60^{\circ} \mathrm{C}$. Another portion of $O$-tert-butyl $N, N^{\prime}$-diisopropylisourea (1 eq., $2.0 \mathrm{~g}, 10.2 \mathrm{mmol})$ in THF $(10 \mathrm{~mL})$ was added and the reaction mixture was stirred at $60{ }^{\circ} \mathrm{C}$ overnight. The resulting mixture was filtered through a Celite pad and the filter cake was washed with $\mathrm{Et}_{2} \mathrm{O}$. The filtrate was concentrated in vacuo. Purification by silica gel flash column chromatography (EtOAc/ heptane $5 \% \rightarrow 30 \%$ ) yielded the title compound as a mixture of diastereoisomers $(2.8 \mathrm{~g}, 7.1 \mathrm{mmol}, \quad 70 \%) .{ }^{1} \mathrm{H} \quad \mathrm{NMR}$ $\left(300 \mathrm{MHz}, \mathrm{CDCl}_{3}\right) \delta=7.39-7.14(\mathrm{~m}, 5 \mathrm{H}, \mathrm{Ph}), 5.68-5.00(\mathrm{~m}, 1 \mathrm{H}$, $\mathrm{NH})$, 4.52-4.04 (m, 3H, $\left.\mathrm{OCH}_{2}, \alpha \mathrm{CH}\right), 3.50-3.33(\mathrm{~m}, 1 \mathrm{H}, \mathrm{OCH})$, 1.95-1.72 (m, 2H, $\left.\mathrm{CH}_{2}\right), 1.62-1.07\left(\mathrm{~m}, 20 \mathrm{H}, \mathrm{CH}_{2}, 6 \times \mathrm{CH}_{3}\right)$,
0.87-0.80 (m, 3H, $\left.\mathrm{CH}_{3}\right)$ ppm. ${ }^{13} \mathrm{C}$ NMR (75 $\left.\mathrm{MHz}, \mathrm{CDCl}_{3}\right) \delta=$ $172.18,172.04,155.72$, 155.45, 138.55, 138.46, 138.35, 128.58, $128.45,128.41,128.28,127.84,127.73,81.65,81.55,79.67$, $79.27,77.16,76.94,71.54,71.04,52.59, \quad 52.18, \quad 36.11$, 35.78, 28.47, 28.19, 28.09, 26.32, 25.95, 9.73, 9.24, 9.00 ppm. HRMS: calculated for $\mathrm{C}_{22} \mathrm{H}_{35} \mathrm{NO}_{5}[\mathrm{M}+\mathrm{H}]^{+}$394.2593; found 394.2582 .

tert-Butyl (2S)-2-((tert-butoxycarbonyl)amino)-4-((methylsulfonyl)oxy)hexanoate (6). Compound 5 (2.8 g, $7.1 \mathrm{mmol})$ was dissolved in methanol $(100 \mathrm{~mL})$, followed by the addition of a catalytic amount of palladium on carbon (10\% wt). The mixture was placed under $\mathrm{H}_{2}$ (4 bar, Parr apparatus) for $48 \mathrm{~h}$. It was filtered through a Celite pad and concentrated in vacuo. The deprotected intermediate was co-evaporated with toluene $(3 \times)$ and dissolved in dry DCM $(70 \mathrm{~mL})$, followed by the addition of $\mathrm{Et}_{3} \mathrm{~N}$ ( 3 eq., $21.3 \mathrm{mmol}, 3.0 \mathrm{~mL}$ ). The reaction solution was cooled to $0^{\circ} \mathrm{C}$ and then methanesulfonyl chloride ( 3 eq., $21.3 \mathrm{mmol}, 1.65 \mathrm{~mL}$ ) was added. After stirring for $3 \mathrm{~h}$ at room temperature, saturated aqueous $\mathrm{NaHCO}_{3}$ was added to the reaction mixture. The mixture was then extracted with DCM $(3 \times)$ and the combined organic layer was dried over $\mathrm{MgSO}_{4}$ and concentrated in vacuo. Purification by silica gel flash column chromatography (EtOAc/heptane 5\% $\rightarrow 30 \%$ ) yielded the title compound as a mixture of diastereoisomers (1.7 g, $4.5 \mathrm{mmol}, 63 \%) .{ }^{1} \mathrm{H}$ NMR (300 $\left.\mathrm{MHz} \mathrm{CDCl}_{3}\right) \delta=$ 5.35-5.20 (m, 1H, NH), 4.65-4.59 (m, 1H, OCH), 4.07-4.02 (m, $1 \mathrm{H}, \alpha \mathrm{CH}), 2.94-2.90\left(\mathrm{~m}, 3 \mathrm{H}, \mathrm{SO}_{3} \mathrm{CH}_{3}\right), 2.07-1.92\left(\mathrm{~m}, 1 \mathrm{H}, \frac{1}{2} \times\right.$ $\left.\mathrm{CH}_{2}\right), 1.85-1.56\left(\mathrm{~m}, 3 \mathrm{H}, 1 \frac{1}{2} \times \mathrm{CH}_{2}\right), 1.40-1.23(\mathrm{~m}, 18 \mathrm{H}, 6 \times$ $\mathrm{CH}_{3}$ ), 0.89-0.78 (m, 3H, $\mathrm{CH}_{3}$ ) ppm. ${ }^{13} \mathrm{C} \mathrm{NMR} \mathrm{(75} \mathrm{MHz,} \mathrm{CDCl}_{3}$ ) $\delta=171.03,170.85,155.36,155.26,82.14,81.94,80.80,80.73$, 79.64, 50.95, 50.89, 38.29, 38.19, 36.17, 35.59, 28.10, 27.96, 27.75, 27.18, 8.69, 8.63 ppm. HRMS: calculated for $\mathrm{C}_{16} \mathrm{H}_{31} \mathrm{NO}_{7} \mathrm{~S}[\mathrm{M}+\mathrm{H}]^{+}$382.1899; found 382.1897.

tert-Butyl (2S)-4-(acetylthio)-2-((tert-butoxycarbonyl)amino) hexanoate (7). Compound $6(1.7 \mathrm{~g}, 4.5 \mathrm{mmol})$ was dissolved in DMF $(25 \mathrm{~mL})$ and potassium thioacetate $(1.54 \mathrm{~g}, 13.5 \mathrm{mmol})$ was added. The resulting reaction mixture was stirred at $65{ }^{\circ} \mathrm{C}$ for $18 \mathrm{~h}$. The reaction mixture was allowed to cool to room temperature and was concentrated in vacuo. The residue was dissolved in EtOAc and the organic layer was washed with brine until the aqueous layer did not show yellow colour anymore $(4 \times)$. The aqueous layer was extracted with EtOAc and the combined organic layers were dried over $\mathrm{MgSO}_{4}$ and concentrated in vacuo. Purification by silica gel flash column chromatography (EtOAc/heptane $5 \% \rightarrow 30 \%$ ) yielded the title compound as a mixture of diastereoisomers (0.98 g, $2.7 \mathrm{mmol}$, $60 \%) .{ }^{1} \mathrm{H}$ NMR (300 MHz, $\left.\mathrm{CDCl}_{3}\right) \delta=5.19-4.95(\mathrm{~m}, 1 \mathrm{H}, \mathrm{NH})$, 4.13-4.06 (m, 1H, $\alpha \mathrm{CH}), 3.48-3.37(\mathrm{~m}, 1 \mathrm{H}, \mathrm{SCH}), 2.17$ (s, 3H, $\mathrm{CH}_{3}$ acetyl), 1.99-1.39 (m, 4H, $\left.\mathrm{CH}_{2}\right), 1.39-1.21(\mathrm{~m}, 18 \mathrm{H}, 6 \times$ $\mathrm{CH}_{3}$ ), 0.85-0.79 (m, 3H, $\mathrm{CH}_{3}$ ) ppm. ${ }^{13} \mathrm{C} \mathrm{NMR} \mathrm{(75} \mathrm{MHz,} \mathrm{CDCl}_{3}$ ) $\delta=195.49,194.85,171.36,155.36,155.04,81.71,79.45,52.18$, $42.41,42.23,37.45,36.95,30.60,30.56,28.22,27.85,27.81$, 26.67, 10.97, 10.91 ppm. HRMS: calculated for $\mathrm{C}_{17} \mathrm{H}_{31} \mathrm{NO}_{5} \mathrm{~S}$ $[\mathrm{M}+\mathrm{H}]^{+}$362.2001; found 362.2003.

tert-Butyl (2S)-2-((tert-butoxycarbonyl)amino)-4-(tert-butyldisulfanyl)hexanoate (8). Compound $7(0.98 \mathrm{~g}, 2.7 \mathrm{mmol})$ and 
S-tert-butyl methane thiosulfonate ${ }^{22}$ (5 eq., $2.27 \mathrm{~g}, 13.5 \mathrm{mmol}$ ) were dissolved in $\mathrm{MeOH}(25 \mathrm{~mL})$, followed by the addition of hydroxylamine hydrochloride (4 eq., $0.75 \mathrm{~g}, 10.8 \mathrm{mmol}$ ) and $\mathrm{Et}_{3} \mathrm{~N}$ (4 eq., $10.8 \mathrm{mmol}, 1.5 \mathrm{~mL}$ ). The resulting reaction mixture was stirred at room temperature. After $2 \mathrm{~h}$, additional $\mathrm{Et}_{3} \mathrm{~N}$ was added ( 2 eq., $5.4 \mathrm{mmol}, 0.75 \mathrm{~mL}$ ) and the reaction mixture was stirred at room temperature until TLC analysis showed the complete conversion of the starting material. The reaction mixture was concentrated in vacuo and the residue was dissolved in EtOAc. The organic layer was washed with $\mathrm{H}_{2} \mathrm{O}, 1 \mathrm{M} \mathrm{KHSO}_{4}$, sat. $\mathrm{NaHCO}_{3}$ and brine. The organic layer was dried over $\mathrm{MgSO}_{4}$ and concentrated in vacuo. Purification by silica gel flash column chromatography (EtOAc/heptane $1 \% \rightarrow 10 \%$ ) yielded the title compound as a mixture of diastereoisomers (693 mg, $1.7 \mathrm{mmol}, 63 \%$ ). ${ }^{1} \mathrm{H} \mathrm{NMR}$ (300 $\mathrm{MHz}, \mathrm{CDCl}_{3}$ ) $\delta=5.06(\mathrm{~d}, J=8.7 \mathrm{~Hz}, 1 \mathrm{H}, \mathrm{NH}), 4.15-4.08(\mathrm{~m}, 1 \mathrm{H}, \alpha \mathrm{CH})$, 2.70-2.62 (m, 1H, SCH), 1.97-1.70 (m, 3H, $\left.1 \frac{1}{2} \times \mathrm{CH}_{2}\right), 1.59-1.47$ $\left(\mathrm{m}, 1 \mathrm{H}, \frac{1}{2} \times \mathrm{CH}_{2}\right), 1.36-1.32\left(\mathrm{~m}, 18 \mathrm{H}, 6 \times \mathrm{CH}_{3}\right), 1.23-1.20(\mathrm{~m}, 9 \mathrm{H}$, $\left.3 \times \mathrm{CH}_{3}\right), 0.94-0.87\left(\mathrm{~m}, 3 \mathrm{H}, \mathrm{CH}_{3}\right) \mathrm{ppm} .{ }^{13} \mathrm{C} \mathrm{NMR}(75 \mathrm{MHz}$, $\left.\mathrm{CDCl}_{3}\right) \delta=171.55,155.31,155.14,81.83,79.44,52.00,50.26$, 47.58, 38.10, 30.04, 28.25, 27.93, 25.93, 10.75 ppm. HRMS: calculated for $\mathrm{C}_{19} \mathrm{H}_{37} \mathrm{NO}_{4} \mathrm{~S}_{2}[\mathrm{M}+\mathrm{H}]^{+}$408.2242; found 408.2239.

(2S)-2-((tert-Butoxycarbonyl)amino)-4-(tert-butyldisulfanyl) hexanoic acid (1). Compound $8(693 \mathrm{mg}, 1.7 \mathrm{mmol})$ was dissolved in trifluoroacetic acid $(10 \mathrm{~mL})$ and stirred at room temperature. The reaction progress was followed by LC-MS. Upon completion, the reaction mixture was concentrated in vacuo and the resulting residue was co-evaporated with toluene $(3 \times)$. The deprotected intermediate was dissolved in $\mathrm{H}_{2} \mathrm{O}(8 \mathrm{~mL})$ and THF $\left(8 \mathrm{~mL}\right.$ ) and cooled to $0{ }^{\circ} \mathrm{C} . \mathrm{K}_{2} \mathrm{CO}_{3}$ (3 eq., $705 \mathrm{mg}$, $5.1 \mathrm{mmol}$ ) was added, followed by the addition of $\mathrm{Boc}_{2} \mathrm{O}$ (2 eq., $742 \mathrm{mg}, 3.4 \mathrm{mmol}$ ) and the reaction mixture was stirred overnight. The aqueous layer was acidified to $\mathrm{pH} 3$ with $1 \mathrm{M}$ $\mathrm{HCl}$ aqueous solution and then extracted with EtOAc $(4 \times)$. The combined organic phase was washed with brine, dried over $\mathrm{MgSO}_{4}$ and concentrated in vacuo. Purification by silica gel flash column chromatography (EtOAc/heptane 10\% $\rightarrow 50 \%$ ) yielded the title compound as a mixture of diastereoisomers (299 mg, $0.85 \mathrm{mmol}, 50 \%) .{ }^{1} \mathrm{H} \mathrm{NMR}\left(300 \mathrm{MHz}, \mathrm{CDCl}_{3}\right) \delta=9.91$ $(\mathrm{s}, 1 \mathrm{H}, \mathrm{OH}), 5.15(\mathrm{~d}, J=8.6 \mathrm{~Hz}, 1 \mathrm{H}, \mathrm{NH}), 4.42-4.16(\mathrm{~m}, 1 \mathrm{H}$, $\alpha \mathrm{CH}), 2.88-2.67(\mathrm{~m}, 1 \mathrm{H}, \mathrm{SCH}), 2.16-1.94\left(\mathrm{~m}, 2 \mathrm{H}, \mathrm{CH}_{2}\right)$, 1.91-1.49 (m, 2H, $\mathrm{CH}_{2}$ ), $1.43\left(\mathrm{~s}, 9 \mathrm{H}, \mathrm{CH}_{3}\right), 1.30\left(\mathrm{~s}, 9 \mathrm{H}, \mathrm{CH}_{3}\right)$, $1.02\left(\mathrm{t}, J=7.3 \mathrm{~Hz}, 3 \mathrm{H}, \mathrm{CH}_{3}\right)$ ppm. ${ }^{13} \mathrm{C} \mathrm{NMR}\left(75 \mathrm{MHz}, \mathrm{CDCl}_{3}\right.$ ) $\delta=177.19,155.75,80.39,51.71,50.57,47.88,38.04,30.21$, 28.41, 26.32, 11.06 ppm. HRMS: calculated for $\mathrm{C}_{15} \mathrm{H}_{29} \mathrm{NO}_{4} \mathrm{~S}_{2}$ $[\mathrm{M}+\mathrm{H}]^{+}$352.1616; found 352.1631.

\section{Synthesis of linear diubiquitin}

Solid phase peptide synthesis. $\mathrm{Ub}\left(1-75, \mathrm{Nle}_{1}\right)$ and $\mathrm{Ub}(2-76)$ (9) polypeptides were synthesized using solid phase peptide synthesis (SPPS). SPPS was performed on a Syro II MultiSyntech Automated Peptide synthesizer using standard 9-fluorenylmethoxycarbonyl (Fmoc) based solid phase peptide chemistry on $25 \mu \mathrm{mol}$ scale, using a fourfold excess of amino acids relative to pre-loaded Fmoc amino acid trityl resin, TentaGel® R TRT-Gly Fmoc (Rapp Polymere GmbH; RA1213;
$0.2 \mathrm{mmol} \mathrm{g}^{-1}$ ), following the previously reported procedure. ${ }^{14 a}$ The resin was washed with NMP and DCM prior to further modifications. The quality and purity of the construct were confirmed by LC-MS analysis (Program 1) of a small amount of the material that was cleaved from the resin using $\mathrm{TFA} / \mathrm{H}_{2} \mathrm{O}$ / DODT/iPr 3 SiH $(90.5 / 5 / 2.5 / 2 ; \mathrm{v} / \mathrm{v} / \mathrm{v} / \mathrm{v} ; 100 \mu \mathrm{L})$ for $30 \mathrm{~min}$ at $37{ }^{\circ} \mathrm{C}$.

Synthesis of $\mathrm{Ub}\left(1-76, \mathrm{Nle}_{1}\right)-\mathrm{S}\left(\mathrm{CH}_{2}\right)_{2} \mathrm{CO}_{2} \mathrm{Me}$ (12). Resin-bound $\mathrm{H}-\mathrm{Ub}\left(1-75, \mathrm{Nle}_{1}\right)$ was washed with DCM $(3 \times 5 \mathrm{~mL}) \cdot \mathrm{Boc}_{2} \mathrm{O}$ (4 eq., $21.83 \mathrm{mg}, 100 \mu \mathrm{mol}, 23 \mu \mathrm{L}$ ) and DiPEA (15 eq., $48.47 \mathrm{mg}, 375 \mu \mathrm{mol}, 65.3 \mu \mathrm{L})$ were dissolved in DCM (1 mL). This solution was added to resin-bound $\mathrm{H}-\mathrm{Ub}\left(1-75, \mathrm{Nle}_{1}\right)$ and the mixture was shaken for 3 hours at room temperature. After 3 hours, the liquid was removed and the resin was washed three times with NMP and DCM alternately followed by three times washing with DCM and MeOH alternately. Boc-Ub(1-75, $\mathrm{Nle}_{1}$ ) was cleaved from the trityl resin using a solution of hexafluoroisopropanol (HFIP) in DCM (1/4; v/v; $2.5 \mathrm{~mL} ; 2 \times 20 \mathrm{~min})$. The resin was rinsed two times with DCM in between HFIP treatments. All combined filtrates were concentrated under reduced pressure. The protected protein was co-evaporated with DCE (3 times, $12 \mathrm{~mL}$ ), to remove traces of HFIP, and lyophilized overnight. Subsequently, the protected protein was dissolved in DCM (4 mL) and reacted with EDC (3 eq., $14.4 \mathrm{mg}, 75 \mu \mathrm{mol}$ ), HOBt (3 eq., $10.1 \mathrm{mg}, 75 \mu \mathrm{mol}$ ) and $\mathrm{HCl} \cdot \mathrm{H}-\mathrm{Gly}-\mathrm{S}\left(\mathrm{CH}_{2}\right)_{2} \mathrm{CO}_{2} \mathrm{Me}(3 \mathrm{eq}$., $16 \mathrm{mg}, 75 \mu \mathrm{mol})$ for 16 hours. To follow the reaction progress a mini deprotection was done. A small amount of the reaction mixture was taken and the protection groups were removed under fast cleavage conditions (TFA/ $\mathrm{H}_{2} \mathrm{O} / \mathrm{DODT} / \mathrm{iPr}_{3} \mathrm{SiH}(90.5 / 5 / 2.5 / 2 ; \mathrm{v} / \mathrm{v} / \mathrm{v} / \mathrm{v} ; 100 \mu \mathrm{L}), 30 \mathrm{~min}$ at $37{ }^{\circ} \mathrm{C}$ ). The reaction was checked by LC-MS analysis (Program 1). The reaction mixture was concentrated under reduced pressure and treated with $\mathrm{TFA} / \mathrm{H}_{2} \mathrm{O} / \mathrm{phenol} / \mathrm{iPr}_{3} \mathrm{SiH}$ $(90.5 / 5 / 2.5 / 2 ; \mathrm{v} / \mathrm{v} / \mathrm{v} / \mathrm{v} ; 5 \mathrm{~mL})$ for 3.5 hours. The protein was precipitated from ice-cold $\mathrm{Et}_{2} \mathrm{O} / n$-pentane $(3 / 1 ; \mathrm{v} / \mathrm{v} ; 20 \mathrm{~mL})$. The solution was centrifuged and $\mathrm{Et}_{2} \mathrm{O} / n$-pentane (supernatant) was removed. The pellet was washed with $\mathrm{Et}_{2} \mathrm{O}(3 \times 20 \mathrm{~mL})$, the solution was vortexed, the suspension was centrifuged and $\mathrm{Et}_{2} \mathrm{O}$ was removed. The wash step was repeated twice. The pellet was dissolved in $\mathrm{H}_{2} \mathrm{O} / \mathrm{CH}_{3} \mathrm{CN} /$ formic acid (65/25/10; $\mathrm{v} / \mathrm{v} / \mathrm{v} ; 10 \mathrm{~mL}$ ) and lyophilized. The protein was subsequently purified using RP-HPLC.

Synthesis of Ub(1-76, ThioNle $_{1}$ ) (11). PyBOP (4 eq., $20.9 \mathrm{mg}$, $40.12 \mu \mathrm{mol})$ was dissolved in NMP $(100 \mu \mathrm{L})$. ThioNle (1, 4 eq., $\sim 14 \mathrm{mg}, 39.82 \mu \mathrm{mol})$ was dissolved in NMP $(200 \mu \mathrm{L})$. Both solutions were added to $\mathrm{Ub}(2-76)$ (9) on resin. DiPEA (8 eq., $10.3 \mathrm{mg}, 79.79 \mu \mathrm{mol}, 13.9 \mu \mathrm{L})$ was dissolved in NMP $(60 \mu \mathrm{L})$ and this solution was also added to the resin. The reaction mixture was shaken overnight. To follow the reaction progress a mini deprotection was done. A small amount of the reaction mixture was taken and the resin and the protection groups were removed under fast cleavage conditions (vide supra). The reaction progress was checked by LC-MS analysis (Program 1). The resin was filtered off, washed three times with DCM and $\mathrm{MeOH}$ alternately, three times with DCM and $\mathrm{Et}_{2} \mathrm{O}$ alternately and three times with $\mathrm{Et}_{2} \mathrm{O}$. 
The polypeptide was deprotected and detached from the resin by treatment with $\mathrm{TFA} / \mathrm{H}_{2} \mathrm{O} /$ phenol/iPr $3 \mathrm{SiH}(90.5 / 5 / 2.5 / 2$; $\mathrm{v} / \mathrm{v} / \mathrm{v} / \mathrm{v} ; 2 \mathrm{~mL}$ ) for $3 \mathrm{~h}$. The reaction mixture was filtered directly into ice-cold $\mathrm{Et}_{2} \mathrm{O} / n$-pentane $(3 / 1 ; \mathrm{v} / \mathrm{v} ; 15 \mathrm{~mL})$ and the resin was spooled with TFA $(2 \times 2 \mathrm{~mL})$. The solution was centrifuged and $\mathrm{Et}_{2} \mathrm{O} / n$-pentane (supernatant) was removed. The pellet was washed with $\mathrm{Et}_{2} \mathrm{O}(3 \times 15 \mathrm{~mL})$, the solution was vortexed, the suspension was centrifuged and $\mathrm{Et}_{2} \mathrm{O}$ was removed. The wash step was repeated twice. The pellet was dissolved in $\mathrm{H}_{2} \mathrm{O}$ / $\mathrm{CH}_{3} \mathrm{CN} /$ formic acid (65/25/10; v/v/v; $5 \mathrm{~mL}$ ) and lyophilized. The protein was subsequently purified using RP-HPLC.

Purification. Crude monoubiquitin was properly dissolved in a minimal amount of DMSO (max. $10 \mathrm{vol} \%$ of the final volume) while being heated carefully. The DMSO was added dropwise into $\mathrm{H}_{2} \mathrm{O}$ (10 to $20 \mathrm{~mL}$ ). The $\mathrm{pH}$ was checked and it should be below 7. The mixture was centrifuged (3 min @3800 rpm). The supernatant was filtered and purified by RP-HPLC on the Waters HPLC. Pure fractions were pooled and lyophilized. The products were obtained as white solids. LC-MS analysis (Program 2) was done to check the purity.

Yields:

$\mathrm{Ub}\left(1-76, \mathrm{Nle}_{1}\right)-\mathrm{S}\left(\mathrm{CH}_{2}\right)_{2} \mathrm{CO}_{2} \mathrm{Me}(12)=229.19 \mathrm{mg}, 26.44 \mu \mathrm{mol}$, $52.88 \%$. LC-MS: $R_{\mathrm{t}}: 4.74$ min: ESI MS+ (amu) calcd: 8649.0 [M], found 8650.0 (deconv.).

Ub(1-76, ThioNle $\left.{ }_{1}\right)(\mathbf{1 1})=32.81 \mathrm{mg}, 3.79 \mu \mathrm{mol}, 37.9 \%$. LC-MS: $R_{\mathrm{t}}$ : $4.92 \mathrm{~min}:$ ESI MS+ (amu) calcd: 8667.1 [M], found 8668.0 (deconv.).

Native chemical ligation of $\mathrm{Ub}\left(1-76, \mathrm{Nle}_{1}\right)-\mathrm{S}\left(\mathrm{CH}_{2}\right)_{2} \mathrm{CO}_{2} \mathrm{Me}$ (12) and $U b\left(1-76\right.$, ThioNle $\left._{1}\right)$ (11). Ub(1-76, ThioNle 1 ) (11, 1 eq., $5.1 \mathrm{mg}, 0.58 \mu \mathrm{mol}$ ) was dissolved in $101.2 \mu \mathrm{L}$ of aqueous buffer containing $8.0 \mathrm{M}$ Gnd. $\mathrm{HCl}$ and $0.2 \mathrm{M} \mathrm{Na}_{2} \mathrm{HPO}_{4}, \mathrm{pH}$ 7.55. $1 \mathrm{M}$ aqueous TCEP solution at $\mathrm{pH} 7.0(12.5 \mu \mathrm{L})$ was added. This solution was pre-incubated for $90 \mathrm{~min}$ and the disulfide bond cleavage was monitored by LC-MS analysis (XEVO). Ub(1-76, Nle $)_{1}-S$ - $\left(\mathrm{CH}_{2}\right)_{2} \mathrm{CO}_{2} \mathrm{Me}(12,1.5$ eq., $7.64 \mathrm{mg}$, $0.88 \mu \mathrm{mol}$ ) was dissolved in $151.9 \mu \mathrm{L}$ of aqueous $8.0 \mathrm{M}$ Gnd. $\mathrm{Hcl}$ and $0.2 \mathrm{M} \mathrm{Na}_{2} \mathrm{HPO}_{4}$ at $\mathrm{pH} 7.55$ and $46.9 \mu \mathrm{L}$ of $1 \mathrm{M}$ MPAA solution was added. This solution was pre-incubated for 5 minutes. Both solutions were properly mixed and the $\mathrm{pH}$ of the reaction mixture was adjusted to 7.45 by the addition of $22 \mu \mathrm{L}$ of $10 \% \mathrm{Na}_{2} \mathrm{CO}_{3}$ solution. The reaction mixture was shaken for $120 \mathrm{~min}$ at $37^{\circ} \mathrm{C}$. The progress of the reaction was checked by LC-MS analysis (XEVO). The diUb formed was purified by RP-HPLC. To prepare the sample, the reaction mixture was added dropwise to $2.5 \mathrm{~mL}$ aqueous buffer containing $6.0 \mathrm{M}$ Gnd $\cdot \mathrm{HCl}$ and $0.15 \mathrm{M} \mathrm{Na} \mathrm{HPO}_{4}$. This solution was diluted with water to $10 \mathrm{~mL} .1 \mathrm{M}$ aqueous TCEP solution at $\mathrm{pH} 7.0$ $(125 \mu \mathrm{L})$ was added. The $\mathrm{pH}$ was checked and adjusted below 7. The mixture was centrifuged (5 min @ $3800 \mathrm{rpm}$ ), filtered and purified by RP-HPLC on the Shimadzu HPLC. Pure fractions were pooled and lyophilized, dissolved in $\mathrm{H}_{2} \mathrm{O} / \mathrm{CH}_{3} \mathrm{CN} /$ formic acid (65/25/10; v/v/v; $15 \mathrm{~mL})$ and lyophilized again. The product was obtained as a white solid. Yield: thiol-containing linear diUb (13) = $2.72 \mathrm{mg} ; 0.159 \mu \mathrm{mol} ; 27.2 \%$.

Desulfurization. Thiol-containing linear diUb was dissolved in aqueous buffer containing 6.0 M Gnd· $\mathrm{HCl}, 0.15 \mathrm{M} \mathrm{Na}_{2} \mathrm{HPO}_{4}$ and $0.25 \mathrm{M}$ TCEP at $\mathrm{pH} 7.0$ to a concentration of $1 \mathrm{mg} \mathrm{mL}^{-1}$ protein. Reduced glutathione (GSH) was added to the solution to a concentration of $100 \mathrm{mM}$. The $\mathrm{pH}$ of the solution was adjusted to 7.20 by the addition of $400 \mu \mathrm{L}$ of $10 \% \mathrm{Na}_{2} \mathrm{CO}_{3}$ solution. VA-044 was added to the solution to a final concentration of $75 \mathrm{mM}$. The reaction mixture was flushed with argon and shaken overnight at $37^{\circ} \mathrm{C}$. The progress of the reaction was checked by LC-MS analysis (Program 1). Desulfurized diUb was purified by RP-HPLC using the Shimadzu HPLC. The reaction mixture was therefore diluted with water (same amount as the reaction volume) and $1 \mathrm{M} \mathrm{NaOAc/AcOH}$ buffer (40 vol\% of the reaction volume). The sample was filled to $10 \mathrm{~mL}$ and the $\mathrm{pH}$ was checked and adjusted below 7; the sample was centrifuged (5 min @ $3800 \mathrm{rpm}$ ) and filtered before it was purified by RP-HPLC. Pure fractions were pooled and lyophilized, dissolved in $\mathrm{H}_{2} \mathrm{O} / \mathrm{CH}_{3} \mathrm{CN} /$ formic acid (65/25/10; v/v/v; $15 \mathrm{~mL}$ ) and lyophilized again.

The product was purified by gel filtration using a Bio-Rad NGC Chromatography system on a size exclusion S75 16/600 superdex PG-GE healthcare column with a volume bed of $120 \mathrm{~mL}$ and 3-70 $\mathrm{kDa}$ separation range using a filtered aqueous buffer containing $50 \mathrm{mM}$ TRIS. $\mathrm{HCl}$ and $100 \mathrm{mM}$ $\mathrm{NaCl}$ at $\mathrm{pH} 7.55$ at a flow rate of $1 \mathrm{~mL} \mathrm{~min}^{-1}$. The sample was prepared by dissolving the product in DMSO $(250 \mu \mathrm{L})$, and dropwise addition of this solution to MilliQ $(2450 \mu \mathrm{L})$ and dropwise addition of $10 \times$ TRIS buffer $(300 \mu \mathrm{L})$. The mixture was centrifuged for $5 \mathrm{~min}$ @3500 rpm. The fractions were analysed by SDS-PAGE analysis and pure fractions were pooled.

The product was obtained as a colourless solution containing $50 \mathrm{mM}$ TRIS. $\mathrm{HCl}$ and $100 \mathrm{mM} \mathrm{NaCl}$ buffer at $\mathrm{pH}$ 7.55. LC-MS analysis (Program 2 and XEVO) was done to check the purity.

The protein concentration (and synthesis yield) was determined by SDS-PAGE analysis and quantification of band intensities after InstantBlue ${ }^{\mathrm{TM}}$ (Expedeon) staining using a GE Healthcare Amersham Imager 600 with ImageQuant TL 8.1 GE Healthcare Life Sciences software. Different amounts monoubiquitin $(0.5 \mu \mathrm{g}, 1 \mu \mathrm{g}, 2 \mu \mathrm{g}$, and $4 \mu \mathrm{g})$ were included on the same gel to calculate the concentration of the final compound. Although quantification of bands from SDS-PAGE analysis is not the most accurate way of quantification, it is the most reliable one due to the relatively low concentration of the solution. Yield: linear diUb $(\mathbf{1 4})=2.54 \mathrm{mg}, 0.15 \mu \mathrm{mol}, 93.4 \%$. LC-MS (Program 2): $R_{\mathrm{t}}$ : 5.18 min: ESI MS+ (amu) calcd: 17075.7 [M], found 17075.00 (deconv.). LC-MS (XEVO): $R_{\mathrm{t}}$ : 4.10 min: ESI MS+ (amu) calcd: 17075.7 [M], found 17077.00 (deconv.)

\section{Expression of linear diubiquitin}

Linear diubiquitin was expressed using a pET17b vector by inducing with $250 \mu \mathrm{M}$ IPTG in BL21 (DE3) cells at an OD of 0.6. Purification was done as described for the yeast ubiquitin proprotein by Larsen et al., 1998. ${ }^{30}$ The concentration was determined using a NanoDrop spectrophotometer and estimated as $20.21 \mathrm{mg} \mathrm{mL}^{-1}(1.18 \mathrm{mM})$. 


\section{Characterization of synthetic and expressed linear diubiquitin}

Purity check and concentration normalization were performed using SDS-PAGE gel analysis. Synthetic (14) and expressed linear diubiquitin were diluted to $\sim 5.85 \mu \mathrm{M}, \sim 11.7 \mu \mathrm{M}$ and $\sim 17.55 \mu \mathrm{M}$ ( $\sim 1, \sim 2$ and $\sim 3 \mu \mathrm{g}$ linear diUb per lane). $10 \mu \mathrm{L}$ of each sample was diluted with $5 \mu \mathrm{L}$ sample buffer $(3 \times)$, containing NUPAGE® LDS sample buffer (4×, Invitrogen) $(900 \mu \mathrm{L})$, $\beta$-mercaptoethanol $(90 \mu \mathrm{L})$ and water $(210 \mu \mathrm{L})$, heated at $95{ }^{\circ} \mathrm{C}$ for 5 minutes and loaded on $12 \%$ NUPAGE® Novex® Bis-Tris Mini Gels (Invitrogen) using MES-SDS running buffer. SeeBlue Pre-stained Plus2 Standard (Invitrogen, LC5925) was used as a marker. InstantBlue ${ }^{\mathrm{TM}}$ (Expedeon) stains were scanned using a GE Healthcare Amersham Imager 600. InstantBlue band intensities were determined using ImageQuant TL 8.1 (GE Healthcare Life Sciences).

\section{Circular dichroism (CD) analysis}

Sample preparation. Synthetic and recombinant diUb were transferred from the buffer containing $50 \mathrm{mM}$ TRIS, $100 \mathrm{mM}$ $\mathrm{NaCl}, \mathrm{pH}=7.55$ to a buffer containing $100 \mathrm{mM}$ sodium phosphate buffer $(\mathrm{pH}=7.41)$. The concentration in $100 \mathrm{mM}$ sodium phosphate was expected to be the same as that in $50 \mathrm{mM}$ TRIS buffer and diluted to a final concentration of $\sim 75 \mu \mathrm{M}$.

The CD measurements were carried out on a JASCO J-815 CD spectrometer fitted with a Peltier temperature controller set to $25{ }^{\circ} \mathrm{C}$. Samples were measured in a quartz cuvette with a $1 \mathrm{~mm}$ path length. Spectra were recorded from 260 to $190 \mathrm{~nm}$ at $1 \mathrm{~nm}$ intervals with a $1 \mathrm{~nm}$ bandwidth. The scan speed was $100 \mathrm{~nm} \mathrm{~min} \mathrm{~m}^{-1}$ and the response time was $1 \mathrm{~s}$. Data were obtained by averaging 5 scans. Data were converted to the mean residue molar ellipticity $\theta\left(\mathrm{deg} \mathrm{cm}^{2} \mathrm{dmol}^{-1}\right)$ according to the equation: ${ }^{31}$

$$
[\theta]=\frac{(\theta)_{\mathrm{obs}}}{c \times n \times l}
$$

where $(\theta)_{\text {obs }}$ is the observed ellipticity in mdeg, $c$ is the peptide concentration in $M$ (expressed linear diUb concentration was corrected with the normalization factor determined by SDS-PAGE), $n$ is the number of residues, and $l$ is the path length of the cuvette in $\mathrm{mm}$. The CD signals, which resulted from the buffer, were subtracted from the spectrum of each sample.

\section{DUB cleavage assays}

USP16 (human, full length (1-823), produced in-house as previously described ${ }^{25 b}$ ), USP21 (human, cat. domain (196-565), Ubiquigent 64-0037-050) and OTULIN (human, full length (1-352), Ubiquigent 64-0048-050) were diluted to $2 \times$ final concentration (150 nM, $740 \mathrm{nM}$ and $13 \mathrm{nM}$, respectively) in a buffer containing $50 \mathrm{mM}$ Tris. $\mathrm{HCl}, 100 \mathrm{mM} \mathrm{NaCl}, \mathrm{pH}$ 7.6, $5 \mathrm{mM}$ DTT and $1 \mathrm{mg} \mathrm{mL} \mathrm{mL}^{-1}$ 3-[(3-cholamidopropyl) dimethylammonio] propanesulfonic acid (CHAPS). Subsequently, $40 \mu \mathrm{L}$ of enzyme was mixed with $40 \mu \mathrm{L}$ of $2 \times$ final concentration of synthetic or recombinant diubiquitin in the same buffer (30.8 $\mu \mathrm{M}$ or $27.3 \mu \mathrm{M}$ respectively). The samples were incubated at $37{ }^{\circ} \mathrm{C}$ for $1,2,5,10,30$ and 180 minutes followed by quenching using a sample buffer containing $\beta$-mercaptoethanol and subsequent SDS gel electrophoresis.

A sample of the reaction mixture was diluted with a sample buffer (3×), containing NUPAGE® LDS sample buffer (4×, Invitrogen) $(900 \mu \mathrm{L}), \beta$-mercaptoethanol $(90 \mu \mathrm{L})$ and water $(210 \mu \mathrm{L})$, heated at $95{ }^{\circ} \mathrm{C}$ for 5 minutes and loaded on $12 \%$ NUPAGE® Novex® Bis-Tris Mini Gels (Invitrogen) using MES-SDS running buffer. A SeeBlue Pre-stained Standard (Invitrogen, LC5925) was used as a marker. InstantBlue ${ }^{\mathrm{TM}}$ (Expedeon) stains were scanned using a GE Healthcare Amersham Imager 600.

\section{Conflicts of interest}

$\mathrm{HO}$ is a shareholder of UbiQ Bio BV.

\section{Acknowledgements}

We thank Gabriëlle van Tilburg and Angela Elhebieshy for linear diubiquitin expression and purification, Dris El Atmioui and Cami Talavera Ormeño for SPPS and Bjorn van Doodewaerd for LC-MS assistance. This work was supported by NWO (VICI grant 724.013.002 to HO).

\section{References}

1 P. E. Dawson, T. W. Muir, I. Clarklewis and S. B. H. Kent, Science, 1994, 266, 776-779.

2 L. Z. Yan and P. E. Dawson, J. Am. Chem. Soc., 2001, 123, 526-533.

3 Q. Wan and S. J. Danishefsky, Angew. Chem., Int. Ed., 2007, 46, 9248-9252.

4 D. Crich and A. Banerjee, J. Am. Chem. Soc., 2007, 129, 10064-100065.

5 (a) J. Chen, Q. Wan, Y. Yuan, J. L. Zhu and S. J. Danishefsky, Angew. Chem., Int. Ed., 2008, 47, 85218524; (b) C. Haase, H. Rohde and O. Seitz, Angew. Chem., Int. Ed., 2008, 47, 6807-6810.

6 J. Chen, P. Wang, J. L. Zhu, Q. Wan and S. J. Danishefsky, Tetrahedron, 2010, 66, 2277-2283.

7 Z. Harpaz, P. Siman, K. S. A. Kumar and A. Brik, ChemBioChem, 2010, 11, 1232-1235.

8 S. Y. Shang, Z. P. Tan, S. W. Dong and S. J. Danishefsky, J. Am. Chem. Soc., 2011, 133, 10784-10786.

9 K. M. Cergol, R. E. Thompson, L. R. Malins, P. Turner and R. J. Payne, Org. Lett., 2014, 16, 290-293.

10 L. R. Malins, K. M. Cergol and R. J. Payne, ChemBioChem, 2013, 14, 559-563.

11 (a) X. Y. Guan, M. R. Drake and Z. P. Tan, Org. Lett., 2013, 15, 6128-6131; (b) R. E. Thompson, B. Chan, L. Radom, K. A. Jolliffe and R. J. Payne, Angew. Chem., Int. Ed., 2013, 52, 9723-9727.

12 P. Siman, S. V. Karthikeyan and A. Brik, Org. Lett., 2012, 14, 1520-1523. 
13 L. R. Malins, K. M. Cergol and R. J. Payne, Chem. Sci., 2014, 5, 260-266.

14 (a) F. El Oualid, R. Merkx, R. Ekkebus, D. S. Hameed, J. J. Smit, A. de Jong, H. Hilkmann, T. K. Sixma and H. Ovaa, Angew. Chem., Int. Ed., 2010, 49, 10149-10153; (b) K. S. A. Kumar, M. Haj-Yahya, D. Olschewski, H. A. Lashuel and A. Brik, Angew. Chem., Int. Ed., 2009, 48, 8090-8094; (c) K. K. Pasunooti, R. L. Yang, S. Vedachalam, B. K. Gorityala, C. F. Liu and X. W. Liu, Bioorg. Med. Chem. Lett., 2009, 19, 6268-6271; (d) R. Merkx, G. de Bruin, A. Kruithof, T. van den Bergh, E. Snip, M. Lutz, F. El Oualid and H. Ovaa, Chem. Sci., 2013, 4, 4494-4498.

15 G. M. Fang, Y. M. Li, F. Shen, Y. C. Huang, J. B. Li, Y. Lin, H. K. Cui and L. Liu, Angew. Chem., Int. Ed., 2011, 50, 7645-7649.

16 S. Varland, C. Osberg and T. Arnesen, Proteomics, 2015, 15, 2385-2401.

17 (a) A. Hershko, H. Heller, E. Eytan, G. Kaklij and I. A. Rose, Proc. Natl. Acad. Sci. U. S. A., 1984, 81, 7021-7025; (b) A. Ciechanover and R. Ben-Saadon, Trends Cell Biol., 2004, 14, 103-106.

18 (a) J. P. Tam and Q. T. Yu, Biopolymers, 1998, 46, 319-327; (b) P. Van de Vijver, L. Scheer, J. van Beijnum, A. Griffioen and T. M. Hackeng, Chem. Commun., 2012, 48, 9403-9405.

19 L. Moroder, J. Pept. Sci., 2005, 11, 187-214.

20 G. M. Ksander, R. deJesus, A. Yuan, R. D. Ghai, A. Trapani, C. McMartin and R. Bohacek, J. Med. Chem., 1997, 40, 495-505.

21 E. Huerta, B. van Genabeek, P. J. M. Stals, E. W. Meijer and A. R. A. Palmans, Macromol. Rapid Commun., 2014, 35, 1320-1325.
22 G. J. van der Heden van Noort, R. Kooij, P. R. Elliott, D. Komander and H. Ovaa, Org. Lett., 2017, 19, 6490-6493.

23 D. Komander and M. Rape, Annu. Rev. Biochem., 2012, 81, 203-229.

24 (a) H. Walczak, K. Iwai and I. Dikic, BMC Biol., 2012, 10, 23; (b) K. Iwai, H. Fujita and Y. Sasaki, Nat. Rev. Mol. Cell Biol., 2014, 15, 503-508.

25 (a) T. E. T. Mevissen, M. K. Hospenthal, P. P. Geurink, P. R. Elliott, M. Akutsu, N. Arnaudo, R. Ekkebus, Y. Kulathu, T. Wauer, F. El Oualid, S. M. V. Freund, H. Ovaa and D. Komander, Cell, 2013, 154, 169-184; (b) A. C. Faesen, M. P. A. Luna-Vargas, P. P. Geurink, M. Clerici, R. Merkx, W. J. van Dijk, D. S. Hameed, F. El Oualid, H. Ovaa and T. K. Sixma, Chem. Biol., 2011, 18, 1550-1561.

26 P. P. Geurink, B. D. M. van Tol, D. van Dalen, P. J. G. Brundel, T. E. T. Mevissen, J. N. Pruneda, P. R. Elliott, G. B. A. van Tilburg, D. Komander and H. Ovaa, ChemBioChem, 2016, 17, 816-820.

27 (a) K. Keusekotten, P. R. Elliott, L. Glockner, B. K. Fiil, R. B. Damgaard, Y. Kulathu, T. Wauer, M. K. Hospenthal, M. Gyrd-Hansen, D. Krappmann, K. Hofmann and D. Komander, Cell, 2013, 153, 1312-1326; (b) A. Weber, P. R. Elliott, A. Pinto-Fernandez, S. Bonham, B. M. Kessler, D. Komander, F. El Oualid and D. Krappmann, Cell Chem. Biol., 2017, 24, 1299-1313.

28 S. Bamezai, M. A. T. Banez and E. Breslow, Biochemistry, 1990, 29, 5389-5396.

29 G. Galley, A. Goergler, Z. K. Groebke Zbinden and R. Norcross, Patent US 2011/0144333A1, 2010.

30 C. N. Larsen, B. A. Krantz and K. D. Wilkinson, Biochemistry, 1998, 37, 3358-3368.

31 N. J. Greenfield, Nat. Protoc., 2006, 1, 2527-2535. 